\title{
Plant Exposures Reported to the Poisons Information Centre Erfurt from 2001-2010
}

Authors

Affiliation
Bettina Plenert, Dagmar Prasa, Helmut Hentschel, Michael Deters

Poisons Information Centre (PIC), Erfurt, Germany
Key words

- plant exposures

- poisoning

- Poisons Information Centre

- Aconitum

- Brugmansia

- Datura

- Ranunculaceae

- Solanaceae

- Taxaceae

- Taxus received Sept. 15, 2011

revised Nov. 16, 2011

accepted January 15, 2012

\section{Bibliography}

DOI http://dx.doi.org/

10.1055/s-0031-1298253

Published online February 9 ,

2012

Planta Med 2012; 78: 401-408

(c) Georg Thieme Verlag KG

Stuttgart · New York .

ISSN 0032-0943

\section{Correspondence}

\section{PD Dr. Med. Michael Deters}

Poisons Information Centre

c/o HELIOS Klinikum GmbH

Nordhäuser Str. 74

99085 Erfurt

Germany

Phone: +49361730730

Fax: + 493617307317

michael_deters2002@yahoo.de

\section{Abstract}

$\nabla$

At the moment, no recent study about plant exposures in Germany and in the federal states the Poisons Information Centre (PIC) Erfurt is serving is available. To get new information about important characteristics of plant exposures like the development of frequency, plants, age groups involved, circumstances of exposure, and symptom severity, we conducted a retrospective study including all human plant exposures reported to the PIC Erfurt over a 10-year period from the beginning of 2001 to the end of 2010. In total, 13001 plant exposures were registered. While the absolute number of plant exposures discontinuously increased from 1110 in 2001 to 1467 in 2009, and decreased to 1157 in 2010, their relative frequency to all human exposures fell from $9.2 \%$ in 2001 to $5.9 \%$ in 2010 . Age groups: children $87.5 \%$ (toddler 60.0\%); adults $11.3 \%$ (middle-aged adults 5.2\%). Gender: female $39.0 \%$ and male 41.2\%. Circumstances: accidental 91.6\%, unknown $4.6 \%$, abuse $2.9 \%$, suicide $0.9 \%$. Severity of symptoms: none to slight $85.5 \%$, moderate $1.7 \%$, unknown $12.7 \%$, severe $0.1 \%$ (in total 9 , one 4 year-old girl, involved plant genera: Aconitum, Arum, Chelidonium, Datura, Brugmansia, Dieffenbachia, Ricinus, 2 Taxus), fatal $0.03 \%$ (in total 4 , involved plant genera: 2 Aconitum, 2 Taxus). In comparison to all human exposures, the relative frequency of severe symptoms in accidental and intentional plant exposures by abuse was significantly lower but as high by suicide. The significant higher involvement of children resulted mainly in none or mild symptoms. Severe symptoms could mostly be observed in adults in intentional plant exposures or when poisonous plants were mistaken for eatable. Because some plant exposures resulted in severe symptoms and even death, their dangerousness should not be trivialised.

$\begin{array}{ll}\text { Abbreviations } \\ \text { A: } & \text { adult of unknown age }>17 \text { years } \\ \text { AE: } & \text { elderly }>65 \text { years } \\ \text { AM: } & \text { middle-aged adult } 18-65 \text { years } \\ \text { C: } & \text { child of unknown age }<14 \text { years } \\ \text { CA: } & \text { adolescent } 14-17 \text { years } \\ \text { CB: } & \text { baby }<1 \text { year } \\ \text { CT: } & \text { toddler } 1-5 \text { years } \\ \text { CS: } & \text { schoolchild } 6-13 \text { years } \\ \text { Cl95: } & \text { 95\% confidence interval for differ- } \\ & \text { ences of the relative frequencies } \\ \text { EP: } & \text { endangering potential } \\ \mathrm{L}_{\text {lower }}: & \text { lower limit of Cl } 95 \\ \mathrm{~L}_{\text {upper }}: & \text { upper limit of Cl } \\ \text { MME: } & \text { moderate and major effects } \\ \mathrm{n}: & \text { number of total cases } \\ \text { p: } & \text { x/n = relative frequency } \\ \text { PIC Erfurt: } & \text { Poisons Information Centre Erfurt } \\ \text { PSS: } & \text { Poisoning Severity Score } \\ \text { SQRT: } & \text { square root } \\ \text { TPE: } & \text { total plant exposures } \\ \text { u: } & \text { age unknown } \\ \text { x: } & \text { number of cases }\end{array}$

posures and the percentage of all exposures registered by U.S. poison centres from 82559 (4.9\%) in 2000 to 54956 (2.4\%) in 2009 was observed. At the moment, no recent study is available about plant exposures in Germany and in the federal states the Poisons Information Centre (PIC) Erfurt is serving. To get new information about impor- 


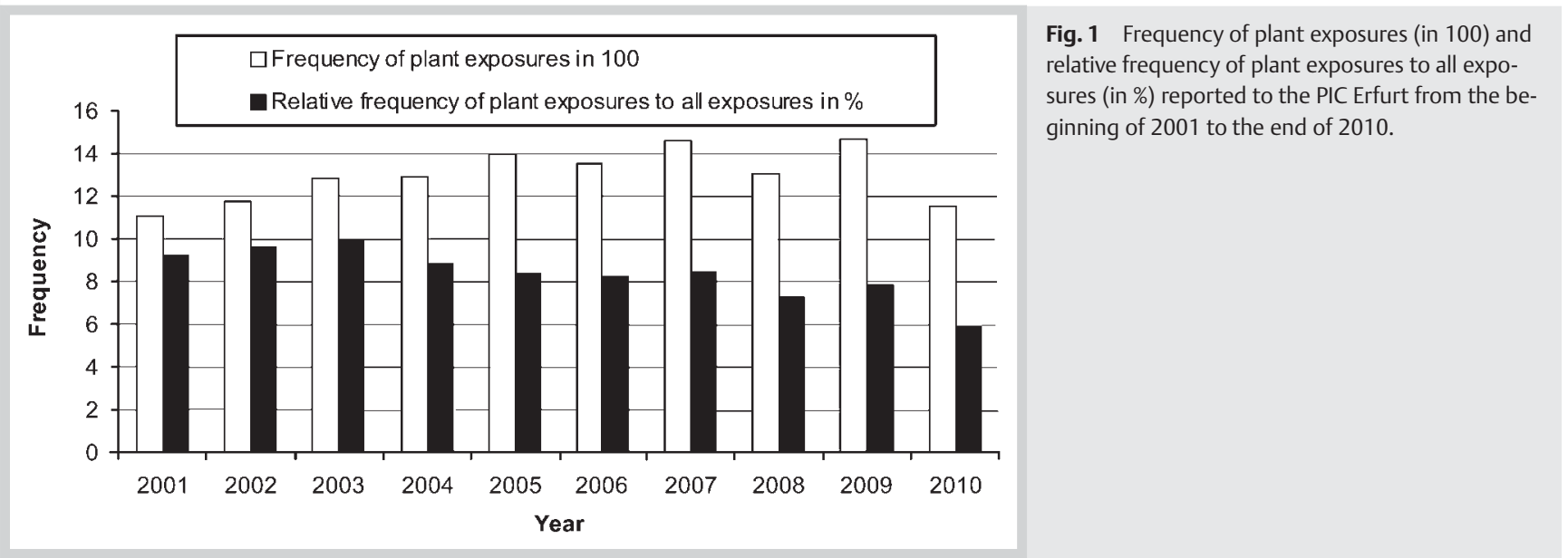

tant characteristics of plant exposures like the development of frequency, plants, age groups involved, circumstances of exposure, and symptom severity, we conducted a retrospective study including all human plant exposures reported to the PIC Erfurt over a 10-year period from the beginning of 2001 to the end of 2010.

\section{Participants and Methods \\ $\nabla$}

The PIC Erfurt serves a population of 10.4 million inhabitants in four federal states (Mecklenburg-Western Pomerania, Saxony, Saxony-Anhalt, and Thuringia) in Germany. All calls regarding acute human plant exposure registered by the PIC Erfurt from 2001 to 2010 were analysed retrospectively. Data were evaluated regarding circumstances of exposure, patient age groups, plants involved, and symptom severity. Age groups were: baby (CB: $<1$ year), toddler (CT: 1 to 5 years), schoolchild (CS: 6 to 13 years), child of unknown age (C: younger than 14 years), adolescent (CA: 14 to 17 years), middle-aged adult (AM: 18 to 65 years), elderly (AE: older than 65 years), adult of unknown age (A: older than 17 years), age unknown $(\mathrm{u})$. The severity of symptoms was classified as none to mild $(0+1)$, moderate (2), severe (3), and fatal, according to the Poisoning Severity Score (PSS) [7]. For all plant genera that caused at least twice moderate or severe symptoms the PSS classification as previously described [2] was used to assess the endangering potential (EP) of the single plant genus from symptoms described in the literature [8-10].

The relative frequencies of symptom severity, age groups, and circumstances of exposure were compared and analysed according to the chi-square test for significant differences $(p<0.05)$ between a plant and all exposures. The $95 \%$ confidence interval $\left(\mathrm{Cl}_{95}\right)$ for the difference of relative frequencies was calculated by approximation to Gaussian distribution for big control samples according to the equation described by Sachs and Hedderich [11]: $\mathrm{L}_{\text {upper}}$ : upper limit of $\mathrm{Cl}_{95}$; $\mathrm{L}_{\text {lower }}$ : lower limit of $\mathrm{Cl}_{95}$; $\mathrm{SQRT}$ : square root; $\mathrm{x}=$ number of cases; $\mathrm{n}=$ number of total cases; $\mathrm{p}=\mathrm{x} / \mathrm{n}=$ relative frequency; $\mathrm{z}=1.96$ for $\mathrm{Cl}_{95}$; for $\mathrm{n} \times \mathrm{p}>5$ and $\mathrm{n} \times(1-\mathrm{p})>5$ :

$\mathrm{L}_{\text {upper }} \approx(\mathrm{p}+1 / 2 \mathrm{n}+\mathrm{z} \times \operatorname{SQRT}(\mathrm{p} \times(1-\mathrm{p}) / \mathrm{n})$;

$\mathrm{L}_{\text {lower }} \approx(\mathrm{p}-1 / 2 \mathrm{n}-\mathrm{z} \times \operatorname{SQRT}(\mathrm{p} \times(1-\mathrm{p}) / \mathrm{n})$.

\section{Results}

In total, the PIC Erfurt registered 13001 plant exposures corresponding to $8.2 \%$ of all exposures from the beginning of 2001 to the end of 2010. While the absolute number of plant exposures discontinuously increased from 1110 in 2001 to 1467 in 2009, and decreased afterwards to 1157 exposures in 2010, the relative frequency to all human exposures fell from $9.2 \%$ in 2001 to $5.9 \%$ in 2010 ( Fig. 1), because the number of all exposures rose from 12012 in 2001 to 19649 in 2010. Plant exposures showed typical seasonal changes with the highest total rates in July (1422), August (2143), September (2179), and October (1639). The lowest total rates of plant exposures were seen in December (570), January (463), February (424), and March (602). The plant genera involved most frequently in plant exposures are summarised in - Table 1. While some plant genera like Taxus, Ligustrum, and Ficus were continuously among the most often involved plant genera during the whole study period, exposures to other plant genera like Brugmansia (decrease from 81 in 2001 to 7 in 2010) showed time-dependent changes.

The distribution of age groups is summarised in 0 Table 2. In comparison to all exposures, plant exposures were significantly more often seen in children of unknown age $(\mathrm{p}<0.05)$ [plant exposures 164 (1.26\%), all exposures 757 (0.48\%)]; babies [plant exposures 2007 (15.44\%), all exposures 6324 (3.99\%)]; toddlers [plant exposures 7803 (60.02\%), all exposures 41964 (26.46\%)]; and schoolchildren [plant exposures 1137 (8.75\%), all exposures $5952(3.75 \%)]$ and significantly less frequently observed in adolescents $(\mathrm{p}<0.05)$ [plant exposures $270(2.08 \%)$, all exposures 8439 (5.32\%)]; adults of unknown age [plant exposures 662 (5.09\%), all exposures 29953 (18.89\%)]; middle-aged adults [plant exposures 682 (5.25\%), all exposures 55797 (35.18\%)]; and the elderly [plant exposures 128 (0.98\%), all exposures 8115 (5.12\%)]. The proportion of each age group in plant and all exposures remained almost unchanged from 2001 to 2010 except for the proportion of adolescents, which decreased from 100 (4.37\%) in 2001 to 20 (0.76\%) in 2010 in plant exposures and for the same period from 2005 (8.23\%) to 1516 (3.95\%) in all exposures. The gender of persons involved in plant exposures was equally distributed amongst females (5062, 39.0\%) and males (5350, $41.2 \%$ ) ( Table 3 ). The circumstance of exposure ( Table 4) was significantly more often accidental in plant $(11894,91.56 \%)$ than in all exposures $(70972,44.93 \%)(\mathrm{p}<0.05)$. Other circumstances of exposure, however, were significantly less frequent in 
Table 1 Top ten plant genera involved in plant exposures reported to the PIC Erfurt from 2001 to 2010.

\begin{tabular}{|c|c|c|c|c|c|c|c|c|c|c|c|}
\hline & 2001 & 2002 & 2003 & 2004 & 2005 & 2006 & 2007 & 2008 & 2009 & 2010 & $\begin{array}{l}2001- \\
2010\end{array}$ \\
\hline 1 & $\begin{array}{l}\text { Brugman- } \\
\text { sia } 81\end{array}$ & $\begin{array}{l}\text { Taxus } \\
72\end{array}$ & $\begin{array}{l}\text { Taxus } \\
67\end{array}$ & $\begin{array}{l}\text { Taxus } \\
78\end{array}$ & $\begin{array}{l}\text { Ligustrum } \\
72\end{array}$ & $\begin{array}{l}\text { Taxus } \\
89\end{array}$ & $\begin{array}{l}\text { Ligustrum } \\
96\end{array}$ & $\begin{array}{l}\text { Ligustrum } \\
82\end{array}$ & $\begin{array}{l}\text { Taxus } \\
129\end{array}$ & $\begin{array}{l}\text { Taxus } \\
65\end{array}$ & $\begin{array}{l}\text { Taxus } \\
742\end{array}$ \\
\hline 2 & $\begin{array}{l}\text { Ligustrum } \\
70\end{array}$ & $\begin{array}{l}\text { Ligustrum } \\
65\end{array}$ & $\begin{array}{l}\text { Lonicera } \\
62\end{array}$ & $\begin{array}{l}\text { Ligustrum } \\
63\end{array}$ & $\begin{array}{l}\text { Ficus } \\
64\end{array}$ & $\begin{array}{l}\text { Sorbus } \\
55\end{array}$ & $\begin{array}{l}\text { Physalis } \\
87\end{array}$ & $\begin{array}{l}\text { Ficus } \\
59\end{array}$ & $\begin{array}{l}\text { Physalis } \\
78\end{array}$ & $\begin{array}{l}\text { Ficus } \\
60\end{array}$ & $\begin{array}{l}\text { Ligustrum } \\
633\end{array}$ \\
\hline 3 & $\begin{array}{l}\text { Ficus } \\
52\end{array}$ & $\begin{array}{l}\text { Brugman- } \\
\text { sia } 49\end{array}$ & $\begin{array}{l}\text { Physalis } \\
50\end{array}$ & $\begin{array}{l}\text { Ficus } \\
61\end{array}$ & $\begin{array}{l}\text { Taxus } \\
63\end{array}$ & $\begin{array}{l}\text { Ligustrum } \\
55\end{array}$ & $\begin{array}{l}\text { Taxus } \\
80\end{array}$ & $\begin{array}{l}\text { Taxus } \\
58\end{array}$ & $\begin{array}{l}\text { Prunus } \\
67\end{array}$ & $\begin{array}{l}\text { Physalis } \\
40\end{array}$ & $\begin{array}{l}\text { Ficus } \\
569\end{array}$ \\
\hline 4 & $\begin{array}{l}\text { Lonicera } \\
43\end{array}$ & $\begin{array}{l}\text { Lonicera } \\
41\end{array}$ & $\begin{array}{l}\text { Ficus } \\
50\end{array}$ & $\begin{array}{l}\text { Physalis } \\
57\end{array}$ & $\begin{array}{l}\text { Physalis } \\
59\end{array}$ & $\begin{array}{l}\text { Ficus } \\
54\end{array}$ & $\begin{array}{l}\text { Ficus } \\
74\end{array}$ & $\begin{array}{l}\text { Physalis } \\
47\end{array}$ & $\begin{array}{l}\text { Ficus } \\
54\end{array}$ & $\begin{array}{l}\text { Ligustrum } \\
37\end{array}$ & $\begin{array}{l}\text { Physalis } \\
519\end{array}$ \\
\hline 5 & $\begin{array}{l}\text { Sorbus } \\
41\end{array}$ & $\begin{array}{l}\text { Ficus } \\
41\end{array}$ & $\begin{array}{l}\text { Ligustrum } \\
47\end{array}$ & $\begin{array}{l}\text { Brugman- } \\
\text { sia } 48\end{array}$ & $\begin{array}{l}\text { Euphorbia } \\
50\end{array}$ & $\begin{array}{l}\text { Prunus } \\
47\end{array}$ & $\begin{array}{l}\text { Prunus } \\
63\end{array}$ & $\begin{array}{l}\text { Prunus } \\
45\end{array}$ & $\begin{array}{l}\text { Lonicera } \\
50\end{array}$ & $\begin{array}{l}\text { Spathi- } \\
\text { phyllum } \\
35\end{array}$ & $\begin{array}{l}\text { Prunus } \\
416\end{array}$ \\
\hline 6 & $\begin{array}{l}\text { Taxus } \\
41\end{array}$ & $\begin{array}{l}\text { Physalis } \\
39\end{array}$ & $\begin{array}{l}\text { Brugman- } \\
\text { sia } 46\end{array}$ & $\begin{array}{l}\text { Prunus } \\
44\end{array}$ & $\begin{array}{l}\text { Lonicera } \\
48\end{array}$ & $\begin{array}{l}\text { Physalis } \\
38\end{array}$ & $\begin{array}{l}\text { Euphorbia } \\
50\end{array}$ & $\begin{array}{l}\text { Crassula } \\
43\end{array}$ & $\begin{array}{l}\text { Ligustrum } \\
46\end{array}$ & $\begin{array}{l}\text { Euphorbia } \\
35\end{array}$ & $\begin{array}{l}\text { Lonicera } \\
405\end{array}$ \\
\hline 7 & $\begin{array}{l}\text { Lathyrus } \\
29\end{array}$ & $\begin{array}{l}\text { Sorbus } \\
37\end{array}$ & $\begin{array}{l}\text { Sorbus } \\
43\end{array}$ & $\begin{array}{l}\text { Lonicera } \\
41\end{array}$ & $\begin{array}{l}\text { Prunus } \\
46\end{array}$ & $\begin{array}{l}\text { Euphorbia } \\
34\end{array}$ & $\begin{array}{l}\text { Mahonia } \\
42\end{array}$ & $\begin{array}{l}\text { Lonicera } \\
38\end{array}$ & Sorbus 44 & $\begin{array}{l}\text { Crassula } \\
27\end{array}$ & $\begin{array}{l}\text { Euphorbia } \\
385\end{array}$ \\
\hline 8 & $\begin{array}{l}\text { Datura } \\
28\end{array}$ & $\begin{array}{l}\text { Euphorbia } \\
33\end{array}$ & $\begin{array}{l}\text { Euphorbia } \\
42\end{array}$ & $\begin{array}{l}\text { Euphorbia } \\
36\end{array}$ & $\begin{array}{l}\text { Sorbus } \\
42\end{array}$ & $\begin{array}{l}\text { Lonicera } \\
30\end{array}$ & $\begin{array}{l}\text { Brugman- } \\
\text { sia } 36\end{array}$ & $\begin{array}{l}\text { Euphorbia } \\
37\end{array}$ & $\begin{array}{l}\text { Euphorbia } \\
42\end{array}$ & $\begin{array}{l}\text { Convallar- } \\
\text { ia } 26\end{array}$ & $\begin{array}{l}\text { Brugman- } \\
\text { sia } 377\end{array}$ \\
\hline 9 & $\begin{array}{l}\text { Euphorbia } \\
26\end{array}$ & $\begin{array}{l}\text { Cotone- } \\
\text { aster } 29\end{array}$ & $\begin{array}{l}\text { Prunus } \\
41\end{array}$ & $\begin{array}{l}\text { Cotone- } \\
\text { aster } 28\end{array}$ & $\begin{array}{l}\text { Brugman- } \\
\text { sia } 39\end{array}$ & $\begin{array}{l}\text { Brugman- } \\
\text { sia } 30\end{array}$ & $\begin{array}{l}\text { Symphori- } \\
\text { carpos } 35\end{array}$ & $\begin{array}{l}\text { Sambu- } \\
\text { cus } 35\end{array}$ & $\begin{array}{l}\text { Lathyrus } \\
41\end{array}$ & $\begin{array}{l}\text { Mahonia } \\
26\end{array}$ & $\begin{array}{l}\text { Sorbus } \\
365\end{array}$ \\
\hline 10 & $\begin{array}{l}\text { Mahonia } \\
25\end{array}$ & $\begin{array}{l}\text { Solanum } \\
29\end{array}$ & $\begin{array}{l}\text { Sambu- } \\
\text { cus } 40\end{array}$ & $\begin{array}{l}\text { Lathyrus } \\
27\end{array}$ & $\begin{array}{l}\text { Sambu- } \\
\text { cus } 31\end{array}$ & $\begin{array}{l}\text { Conval- } \\
\text { laria } 29\end{array}$ & $\begin{array}{l}\text { Lonicera } \\
32\end{array}$ & $\begin{array}{l}\text { Sorbus } \\
34\end{array}$ & $\begin{array}{l}\text { Crassula } \\
34\end{array}$ & $\begin{array}{l}\text { Zamiocul- } \\
\text { cas } 24\end{array}$ & $\begin{array}{l}\text { Mahonia } \\
279\end{array}$ \\
\hline
\end{tabular}

plant than in all exposures $(\mathrm{p}<0.05)$ [abuse: plant exposures 371 (2.86\%), all exposures 6040 (3.81\%); suicide: plant exposures 119 (0.94\%), all exposures 210 (36.08\%); unknown: plant exposures 617 (4.6\%), all exposures 24378 (15.17\%)]. The symptom severity ( Table 4) was significantly more often none to mild in plant exposures $(11114,85.5 \%)$ than in all exposures $(103334,65.20 \%)$ $(p<0.05)$. The other symptom severity grades occurred significantly less frequently in plant than in all exposures $(\mathrm{p}<0.05)$ [moderate: plant exposures 220 (1.69\%), all exposures 11635 (7.33\%); severe: plant exposures 9 (0.07\%), all exposures 5504 (3.47\%); unknown: plant exposures 1654 (12.70\%), all exposures 37828 (23.90\%); death: plant exposures 4 (0.03\%), all exposures $299(0.18 \%)]$. Information on symptom severity in relation to the circumstances of plant and all exposures is given in 0 Table 4. Accidental plant exposures resulted significantly more often in none to mild symptoms $(10578,88.94 \%)$ than in all accidental exposures (58672, 82.67\%) $(\mathrm{p}<0.05)$. Moderate and severe symptoms as well as fatalities and unknown symptoms occurred significantly more frequently in all accidental exposures [moderate symptoms: 1730 (2.44\%); severe symptoms: 351 (0.49\%)] than in accidental plant exposures [moderate symptoms: 97 $(0.82 \%)$; severe symptoms: $4(0.03 \%)](\mathrm{p}<0.05)$ ( Table 4$)$. Intentional plant exposures by abuse caused significantly less none to mild $(84,22.64 \%)$ and severe symptoms $(1,0.27 \%)$ than all intentional exposures by abuse ( $\mathrm{p}<0.05$ ) [none to mild symptoms: 2141 (35.45\%); severe symptoms: 429 (7.10\%)] (๑ Table 4). Plant exposures with suicidal intention, however, showed nearly the same frequency of the symptom severity as all exposures in suicidal intention ( Table 4). Fatalities, however, were even significantly more frequent with suicidal plant exposures (4, 3.36\%) than in all exposures $(88,0.36 \%)$ with suicidal intention $(p<0.05)$ ( Table 4). No significant differences between female and male persons in plant and all exposures concerning the symptom severity could be observed ( Table 3 ).

More detailed information on plant exposures with severe symptoms or even a fatal outcome is given in 0 Table 5. In total, only 9 severe plant exposures (plant genera: Aconitum, Arum, Chelido- nium, Datura, Brugmansia, Dieffenbachia, Ricinus, 2 Taxus) were observed. A child (4-year-old girl) was involved only once. In four cases (plant genera: 2 Aconitum, 2 Taxus), the outcome of the plant exposure was fatal.

- Table 6 shows all plant genera that caused at least twice moderate or severe symptoms after exposure. The most frequent moderate or severe symptoms were seen in exposures to Brugmansia (54), Datura (23), and Euphorbia (17).

\section{Discussion}

As described above, the U.S. poison centres registered a steady decline of $33 \%$ of the relative percentage as well as of the absolute number of plant exposures during the decade of 2000-2009 [6]. This decline was even more dramatic (a decrease of $400 \%$ ) if a time period over 3 decades (1983-2009) was investigated. The authors explained this phenomenon with the increasing use of the Internet for identifying plants and getting information about them. In Germany, the use of the Internet in persons older than 14 years also rose from $38.8 \%$ in 2001 to $69.4 \%$ in 2010 [13]. In the present study, plant exposures reported to the PIC Erfurt discontinuously increased from 1110 in 2001 to 1467 in 2009 and decreased afterwards to 1157 in 2010 ( Fig. 1). Therefore, from our point of view, the hypothesis that augmented Internet use resulted in a decreased number of calls concerning plant exposure seems to be questionable, at least for the federal states that the PIC Erfurt is serving.

Like in the U.S. [6], in our present study plant exposures were mostly seen during the more temperate months of the northern hemisphere. Differences, however, were observed in the rank order of the most common plant exposures. While in the U.S. study Spathiphyllum, Ilex, Philodendron, Euphorbia, Phytolacca, Fragaria, Hemerocallis, Schefflera, Calendula, and Ficus were among the 10 most frequent plant exposures, the rank order in our study was Taxus, Ligustrum, Ficus, Physalis, Prunus, Lonicera, Euphorbia, Brugmansia, Sorbus, and Mahonia, which is comparable, with 


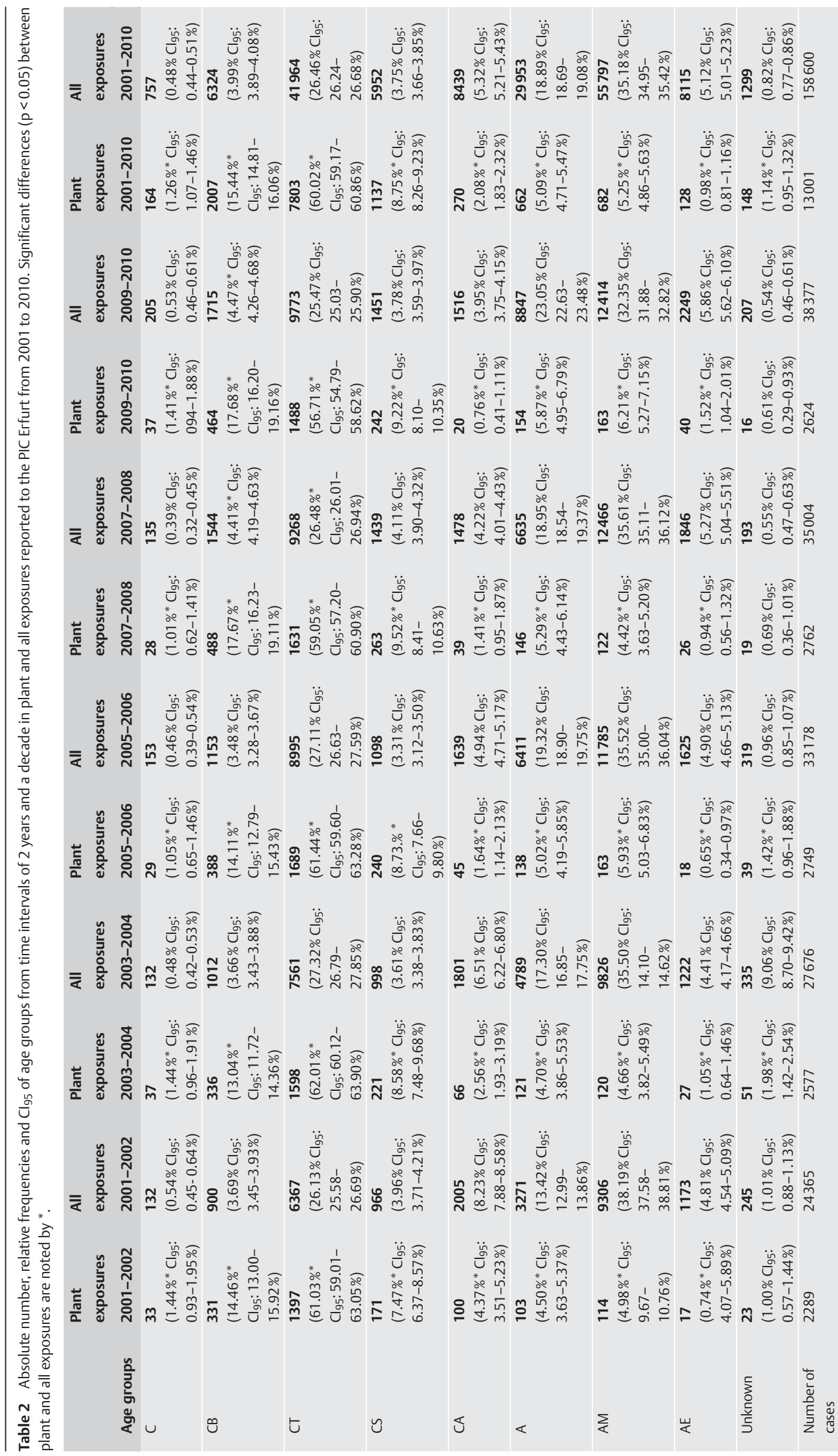


Table 3 Absolute number, relative frequencies, and $\mathrm{Cl}_{95}$ of symptom severity in the single gender groups in plant and all exposures reported to the PIC Erfurt from 2001 to 2010 .

\begin{tabular}{|c|c|c|c|c|c|c|}
\hline \multirow[b]{2}{*}{ Symptom severity } & \multicolumn{3}{|c|}{ Plant exposures - Gender } & \multicolumn{3}{|c|}{ All exposures - Gender } \\
\hline & Male & Female & Unknown & Male & Female & Unknown \\
\hline $0+1$ & $\begin{array}{l}4519 \\
\left(84.47 \% \mathrm{Cl}_{95}:\right. \\
83.49-85.45 \%)\end{array}$ & $\begin{array}{l}4386 \\
\left(86.63 \% \mathrm{Cl}_{95}:\right. \\
85.68-87.58 \%)\end{array}$ & $\begin{array}{l}2209 \\
\left(85.32 \% \mathrm{Cl}_{95}:\right. \\
83.70-86.44 \%)\end{array}$ & $\begin{array}{l}42882 \\
\left(64.46 \% \mathrm{Cl}_{95}:\right. \\
64.10-64.82 \%)\end{array}$ & $\begin{array}{l}48715 \\
\left(64.17 \% \mathrm{Cl}_{95}:\right. \\
63.83-64.51 \%)\end{array}$ & $\begin{array}{l}11737 \\
\text { (72.65\% Cl95: } \\
71.96-73.34 \%)\end{array}$ \\
\hline 2 & $\begin{array}{l}119 \\
\left(2.22 \% \mathrm{Cl}_{95}: 1.82-\right. \\
2.62 \%)\end{array}$ & $\begin{array}{l}86 \\
\left(1.70 \% \mathrm{Cl}_{95}:\right. \\
1.33-2.07 \%)\end{array}$ & $\begin{array}{l}15 \\
\left(0.58 \% \mathrm{Cl}_{95}:\right. \\
0.27-0.89 \%)\end{array}$ & $\begin{array}{l}\mathbf{5 1 7 0} \\
\left(7.77 \% \mathrm{Cl}_{95}:\right. \\
7.57-7.97 \%)\end{array}$ & $\begin{array}{l}\mathbf{5 8 9 9} \\
\left(7.77 \% \mathrm{Cl}_{95}:\right. \\
7.58-7.96 \%)\end{array}$ & $\begin{array}{l}\mathbf{5 6 6} \\
\left(3.50 \% \mathrm{Cl}_{95}:\right. \\
3.22-3.79 \%)\end{array}$ \\
\hline 3 & $\begin{array}{l}3 \\
\left(0.06 \% \mathrm{Cl}_{95}: \text { n.c. }\right)\end{array}$ & $\begin{array}{l}6 \\
\left(0.12 \% \mathrm{Cl}_{95}:\right. \\
0.01-0.23 \%)\end{array}$ & $\begin{array}{l}\mathbf{0} \\
\left(0 \% \mathrm{Cl}_{95}: \text { n.c. }\right)\end{array}$ & $\begin{array}{l}2501 \\
\left(3.76 \% \mathrm{Cl}_{95}:\right. \\
3.61-3.91 \%)\end{array}$ & $\begin{array}{l}2835 \\
\left(3.73 \% \mathrm{Cl}_{95}:\right. \\
3.59-3.87 \%)\end{array}$ & $\begin{array}{l}168 \\
\left(1.04 \% \mathrm{Cl}_{95}:\right. \\
0.88-1.20 \%)\end{array}$ \\
\hline Fatal & $\begin{array}{l}1 \\
\left(0.02 \% \mathrm{Cl}_{95}: \text { n.c. }\right)\end{array}$ & $\begin{array}{l}\mathbf{3} \\
\left(0.06 \% \mathrm{Cl}_{95}: \text { n.c. }\right)\end{array}$ & $\begin{array}{l}\mathbf{0} \\
\left(0 \% \mathrm{Cl}_{95} \text { : n.c. }\right)\end{array}$ & $\begin{array}{l}152 \\
\left(0.23 \% \mathrm{Cl}_{95}:\right. \\
0.19-0.27 \%)\end{array}$ & $\begin{array}{l}127 \\
\left(0.17 \% \mathrm{Cl}_{95}:\right. \\
0.14-0.20 \%)\end{array}$ & $\begin{array}{l}20 \\
\left(0.12 \% \mathrm{Cl}_{95}:\right. \\
0.07-0.18 \%)\end{array}$ \\
\hline Unknown & $\begin{array}{l}708 \\
\left(13.23 \% \mathrm{Cl}_{95}:\right. \\
12.32-14.16 \%)\end{array}$ & $\begin{array}{l}\mathbf{5 8 1} \\
\left(11.48 \% \mathrm{Cl}_{95}:\right. \\
10.59-12.37 \%)\end{array}$ & $\begin{array}{l}365 \\
\left(14.10 \% \mathrm{Cl}_{95}:\right. \\
12.74-15.46 \%)\end{array}$ & $\begin{array}{l}15822 \\
\left(23.78 \% \mathrm{Cl}_{95}:\right. \\
23.46-24.10 \%)\end{array}$ & $\begin{array}{l}18341 \\
\left(24.16 \% \mathrm{Cl}_{95}:\right. \\
23.85-24.47 \%)\end{array}$ & $\begin{array}{l}3665 \\
\left(25.93 \% \mathrm{Cl}_{95}:\right. \\
25.25-26.60 \%)\end{array}$ \\
\hline Number of cases & 5350 & 5062 & 2589 & 66527 & 75917 & 16156 \\
\hline
\end{tabular}

n.c. $=$ not calculated

small differences, to the rank order seen in other studies conducted in Germany [2] and Switzerland [3-5].

While the rate of accidental exposures to plant genera like Taxus, Ligustrum, and Ficus was continuously high during the whole study period, the exposure by abuse to plant genera like Brugmansia and Datura showed time-dependent changes with the highest rate being in 2001 and a decreasing frequency in the following years. Concurrently, with the decrease of Datura and Brugmansia exposure, the proportion of adolescents compared to the other age groups in plant exposures was also reduced, while the proportion of the other age groups involved in plant exposures remained quite stable ( 0 Table 2). Datura and Brugmansia genera were mainly abused by adolescents and young adults, and were mostly responsible for moderate or severe symptoms in plant exposures in our study and in other studies as well $[1-6,12,14]$ ( Table 6). Unfortunately, in these studies no information was given if the exposure to these plant genera by abuse was also decreasing.

In the above-mentioned U.S. study [6], nearly $55 \%$ of the plantrelated fatalities involved males and slightly more than $60 \%$ of the exposures that had a moderate or major outcome occurred in males. In our present study, no such gender specific influence on the symptom severity was observed ( 0 Table $\mathbf{3}$ ).

In our study as well as in other studies [1-6,12], plant exposures more frequently resulted in none to mild symptoms and less often resulted in moderate and severe symptoms, and even death, than all exposures. These results can at least partially be explained by the fact that the proportion of babies and toddlers and accidental exposure was significantly higher, and the proportion of adults and intentional exposure by abuse and suicide was significantly lower in plant exposures than in all exposures ( $\triangle$ Table 4). To exclude the influence of the circumstances of exposure on symptom severity, we directly compared the frequencies of symptom severity in the single circumstance groups in plant and all exposures ( $\bullet$ Table 4 ). After this procedure, accidental plant exposures also resulted more often in none to mild symptoms and resulted less often in moderate and severe symptoms, and even death, than all accidental exposures; but these differences were less pronounced than in the analysis regardless of the circumstances of exposure. In plant exposures by abuse, significant differences to all exposures by abuse were only seen for the frequencies of none to mild and severe symptoms. When exposure occurred due to suicidal intention, no significant difference between plant and all exposures concerning symptoms with none to high severity was observed. Fatalities, however, were even more significantly $(\mathrm{p}<0.05)$ frequent in suicidal plant exposures than in all exposures due to suicidal intention (O Table 4).

As can be seen in 0 Table $\mathbf{5}$, we observed only 9 severe plant exposures (plant genera: Aconitum, Arum, Chelidonium, Datura, Brugmansia, Dieffenbachia, Ricinus, 2 Taxus) and four fatal cases (plant genera: 2 Aconitum, 2 Taxus) (๑ Table 4). While in the U.S. study mainly Datura and Cicuta species were responsible for fatal outcomes and only one Taxus chinensis exposure resulted in death, no fatality after Aconitum napellus exposure was observed [6]. In Switzerland, 3 of 4 fatal plant exposures were caused by Colchicum autumnale and one by Taxus baccata.

While Aconitum contains the sodium channel activators aconitine and related alkaloids in all parts of the plant, especially in the leaves and roots, in Taxus baccata, most of the plant, including the seeds but not the red aril, contains the toxic taxine alkaloids that block sodium and calcium currents [8]. Most paediatric cases of Taxus baccata exposure involve ingestion of the seeds and aril with usually none to minimal symptoms. Therefore, the toxic potential of Taxus baccata could be underestimated [15]. Substantial ingestion of the leaves, however, that ocurrs mainly with the intention of suicide can result in severe cardiovascular effects including bradycardia, premature ventricular contractions, atrioventricular conduction defects, or ventricular tachydysrhythmias [16].

Betweeen 2001 and 2010, 20\% of all exposures in children registered by the PIC Erfurt concerned plant exposures. The main groups of callers due to plant exposure besides private persons (8212, 63.0\%) were physicians from hospitals $(2217,17.1 \%)$ and general practitioners or practice-based paediatricians (1624, $12.5 \%$. These data show that the clinical significance of plant exposure is high because the knowledge about plants and their toxicity in the general public as well as in health care professionals seems to be low. 


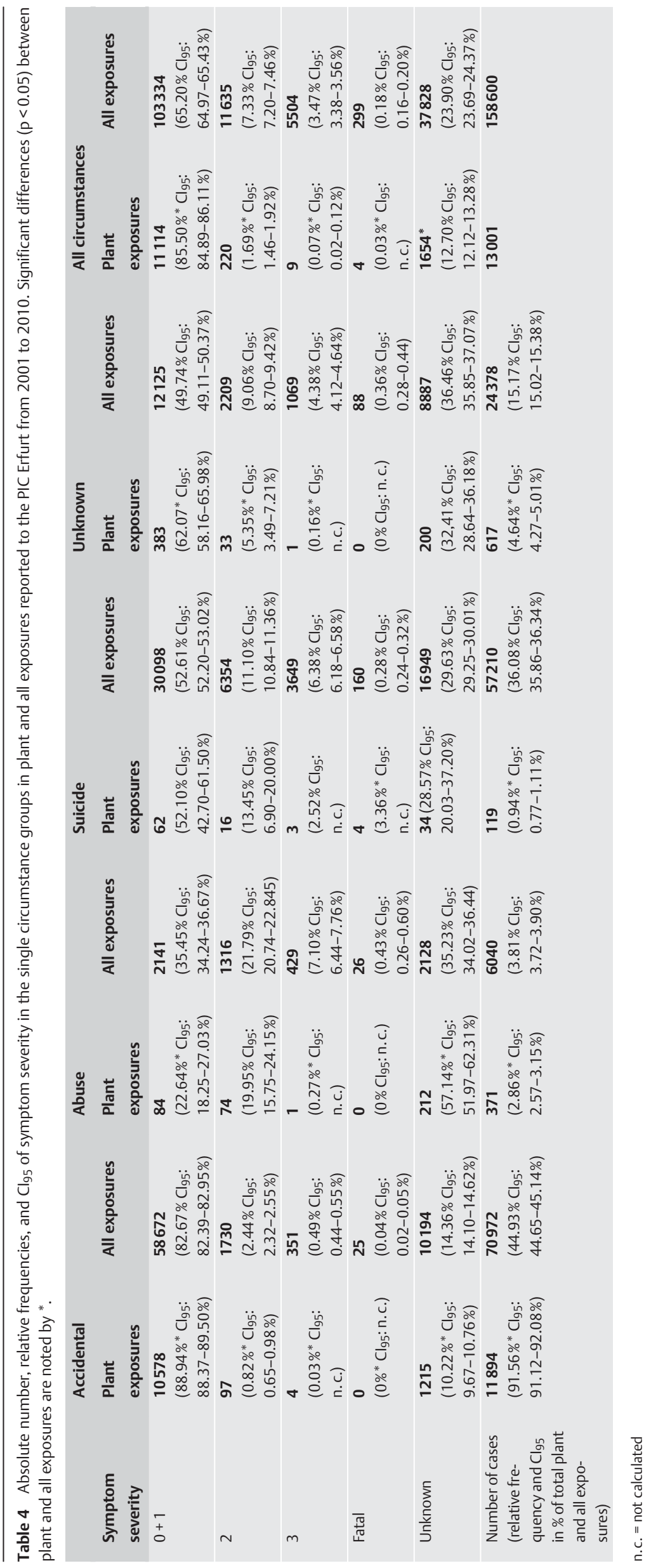


Table 5 Cases of plant exposures that resulted in severe symptoms or even death reported to the PIC Erfurt from 2001-2010.

\begin{tabular}{|c|c|c|c|c|c|}
\hline $\begin{array}{l}\text { Case } \\
\text { number }\end{array}$ & Plant & $\begin{array}{l}\text { Circumstances } \\
\text { of exposure }\end{array}$ & Patient & Symptoms & Measures \\
\hline 1 & $\begin{array}{l}\text { Aconitum napellus } \\
\text { unknown amount }\end{array}$ & suicidal ingestion & $\begin{array}{l}\text { woman, age } \\
\text { unknown }\end{array}$ & $\begin{array}{l}\text { initially no symptoms, after- } \\
\text { wards death }\end{array}$ & no treatment \\
\hline 2 & $\begin{array}{l}\text { Aconitum napellus } \\
\text { unknown amount of a } \\
\text { soup from the plant }\end{array}$ & suicidal ingestion & $\begin{array}{l}\text { 63-year-old } \\
\text { man }\end{array}$ & $\begin{array}{l}20 \text { min after ingestion first } \\
\text { symptoms with malaise, } \\
\text { vomiting, abdominal pain, } \\
\text { coma, respiratory insuffi- } \\
\text { ciency, hyporeflexia, hypo- } \\
\text { thermia, bradycardia ( } 54 \\
\text { beats/min), initial hyperten- } \\
\text { sion then hypotension (sys- } \\
\text { tolic RR } 40 \text { mmHg), in X-ray } \\
\text { atelectasis of the left lung }\end{array}$ & $\begin{array}{l}\text { intubation and ventilation, gastric lavage, } \\
\text { activated charcoal plus sodium sulfate, } \\
\text { cardiopulmonary monitoring, catechol- } \\
\text { amines, infusion, sedation with propofol, } \\
\text { acetylcysteine and antibiotics to treat } \\
\text { bronchopneumonia }\left(38^{\circ} \mathrm{C}\right) \text { in the further } \\
\text { course, recovered completely }\end{array}$ \\
\hline 3 & $\begin{array}{l}\text { Aconitum napellus un- } \\
\text { known amount of a liquid } \\
\text { extraction from the plant }\end{array}$ & suicidal ingestion & $\begin{array}{l}\text { 74-year-old } \\
\text { man }\end{array}$ & $\begin{array}{l}\text { coma, respiratory failure, hy- } \\
\text { potension }\end{array}$ & $\begin{array}{l}\text { died in the further course of treatment at } \\
\text { an intensive care unit }\end{array}$ \\
\hline 4 & $\begin{array}{l}\text { Arum cornutum unknown } \\
\text { amount of the root tuber }\end{array}$ & $\begin{array}{l}\text { accidental inges- } \\
\text { tion, mix-up with } \\
\text { celery }\end{array}$ & $\begin{array}{l}\text { man, age un- } \\
\text { known }\end{array}$ & $\begin{array}{l}\text { swelling of the left side of the } \\
\text { tongue and pharynx, respira- } \\
\text { tory insufficiency }\end{array}$ & $\begin{array}{l}\text { cardiopulmonary monitoring, antihista- } \\
\text { minics, improvement of the symptoms in } \\
\text { the further course }\end{array}$ \\
\hline 5 & $\begin{array}{l}\text { Chelidonium majus } \\
\text { unknown amount }\end{array}$ & $\begin{array}{l}\text { accidental inges- } \\
\text { tion as herbage }\end{array}$ & $\begin{array}{l}\text { man, age un- } \\
\text { known }\end{array}$ & $\begin{array}{l}\text { jaundice, convulsion, shortly } \\
\text { high elevation of transami- } \\
\text { nases }\end{array}$ & $\begin{array}{l}\text { viral hepatitis was excluded, symptomatic } \\
\text { treatment, transaminases decreased in } \\
\text { the further course }\end{array}$ \\
\hline 6 & $\begin{array}{l}\text { Datura stramonium } \\
\text { unknown amount of tea } \\
\text { prepared from seeds }\end{array}$ & $\begin{array}{l}\text { ingestion for un- } \\
\text { known reason }\end{array}$ & $\begin{array}{l}\text { 42-year-old } \\
\text { woman }\end{array}$ & $\begin{array}{l}\text { initially coma, in the further } \\
\text { course apathia, pronounced } \\
\text { agitation, tachycardia, my- } \\
\text { driasis }\end{array}$ & $\begin{array}{l}\text { cardiopulmonary monitoring, infusion, } \\
\text { clonidine, nitroglycerin, diazepam, halo- } \\
\text { peridol, single dose of physostigmine and } \\
\text { furosemide, recovered completely }\end{array}$ \\
\hline 7 & $\begin{array}{l}\text { Brugmansia } \\
\text { unknown amount }\end{array}$ & abusal ingestion & $\begin{array}{l}17 \text {-year-old } \\
\text { girl }\end{array}$ & $\begin{array}{l}\text { pronounced psychotic reac- } \\
\text { tion, tachycardia ( } 180 \text { beats/ } \\
\text { min), mydriasis }\end{array}$ & $\begin{array}{l}\text { ipecac-induced emesis, activated char- } \\
\text { coal, cardiopulmonary monitoring, un- } \\
\text { known outcome }\end{array}$ \\
\hline 8 & $\begin{array}{l}\text { Dieffenbachia unknown } \\
\text { amount of plant juice }\end{array}$ & $\begin{array}{l}\text { accidental der- } \\
\text { mal contamina- } \\
\text { tion of an open } \\
\text { wound of the } \\
\text { thumb } 1 \text { month } \\
\text { ago }\end{array}$ & $\begin{array}{l}\text { 42-year-old } \\
\text { woman }\end{array}$ & dermal necrosis & $\begin{array}{l}\text { surgical debridement and plastic coverage } \\
\text { of the wound, delayed wound healing, no } \\
\text { underlying disease (diabetes) was known }\end{array}$ \\
\hline 9 & $\begin{array}{l}\text { Ricinus communis } \\
\text { unknown amount of } \\
\text { leaves }\end{array}$ & $\begin{array}{l}\text { accidental inges- } \\
\text { tion, mix-up with } \\
\text { leaves from } \\
\text { Rheum rhabarba- } \\
\text { rum }\end{array}$ & $\begin{array}{l}\text { 4-year-old } \\
\text { girl }\end{array}$ & $\begin{array}{l}\text { permanent vomiting, bloody } \\
\text { aqueous diarrhoea, hypoten- } \\
\text { sion, hypothermia }\end{array}$ & $\begin{array}{l}\text { intravenous administration of fluid and } \\
\text { electrolytes, diagnostically no other cause } \\
\text { was found, unknown outcome }\end{array}$ \\
\hline 10 & $\begin{array}{l}\text { Taxus baccata unknown } \\
\text { amount of leaves }\end{array}$ & suicidal ingestion & $\begin{array}{l}16 \text {-year-old } \\
\text { girl }\end{array}$ & $\begin{array}{l}\text { initially malaise, uncon- } \\
\text { sciousness, in autopsy pro- } \\
\text { nounced mydriasis, brain and } \\
\text { lung oedema, congestion in } \\
\text { liver, spleen, and kidneys }\end{array}$ & $\begin{array}{l}\text { resuscitation, death, in autopsy big } \\
\text { amounts of Taxus baccata leaves in larynx, } \\
\text { oesophagus, stomach and duodenum }\end{array}$ \\
\hline 11 & $\begin{array}{l}\text { Taxus baccata unknown } \\
\text { amount of leaves }\end{array}$ & suicidal ingestion & $\begin{array}{l}\text { woman, age } \\
\text { unknown }\end{array}$ & $\begin{array}{l}\text { no information, the woman } \\
\text { was found dead }\end{array}$ & $\begin{array}{l}\text { in postmortem analysis the serum con- } \\
\text { centration of 3,5-dimethoxyphenol was } \\
60 \mu \mathrm{g} / \mathrm{L}\end{array}$ \\
\hline 12 & $\begin{array}{l}\text { Taxus baccata unknown } \\
\text { amount of leaves }\end{array}$ & suicidal ingestion & $\begin{array}{l}\text { 48-year-old } \\
\text { woman }\end{array}$ & $\begin{array}{l}\text { coma, respiratory and renal } \\
\text { failure, hypotonia }\end{array}$ & $\begin{array}{l}\text { intubation and ventilation, gastric lavage, } \\
\text { activated charcoal, cardiopulmonary } \\
\text { monitoring, recovered completely }\end{array}$ \\
\hline 13 & $\begin{array}{l}\text { Taxus baccata unknown } \\
\text { amount of leaves }\end{array}$ & suicidal ingestion & $\begin{array}{l}\text { 52-year-old } \\
\text { woman }\end{array}$ & $\begin{array}{l}\text { coma, asystole, after resusci- } \\
\text { tation and defibrillation bra- } \\
\text { dycardia with escape rhythm, } \\
\text { pronounced QRS complex } \\
\text { widening }\end{array}$ & $\begin{array}{l}\text { intubation and ventilation, gastric lavage, } \\
\text { multiple-dose activated charcoal, cardio- } \\
\text { pulmonary monitoring, pacemaker instal- } \\
\text { lation, lidocaine ( } 50 \mathrm{mg} \text { as i. v. bolus and } \\
1 \mathrm{~g} / 24 \mathrm{~h} \text { ) reduced remarkably the QRS } \\
\text { complex widening, recovered completely } \\
\text { after } 7 \text { days of treatment at an intensive } \\
\text { care unit }\end{array}$ \\
\hline
\end{tabular}




\begin{tabular}{|lllll|}
\hline Plant genera & EP & TPE & MME & MME/TPE in \% \\
\hline Brugmansia & +++ & 377 & 54 & 14.3 \\
\hline Datura & +++ & 127 & 23 & 18.1 \\
\hline Euphorbia & + & 385 & 17 & 4.4 \\
\hline Taxus & +++ & 742 & 9 & 1.2 \\
\hline Atropa & +++ & 53 & 6 & 11.3 \\
\hline Heracleum & ++ & 59 & 6.2 & 3.5 \\
\hline Laburnum & ++ & 143 & 5 & 1.9 \\
\hline Sambucus & + & 268 & 5 & 3.5 \\
\hline Narcissus & + & 115 & 4 & 7.0 \\
\hline Aconitum & +++ & 43 & 3 & 42.9 \\
\hline Dictamnus & ++ & 7 & 3 & 1.4 \\
\hline Dieffenbachia & ++ & 210 & 3 & 4.5 \\
\hline Digitalis & ++ & 67 & 3 & 7.5 \\
\hline Ricinus & +++ & 40 & 3 & 1.2 \\
\hline Solanum & ++ & 246 & 3 & 3.4 \\
\hline Colchicum & +++ & 59 & 2 & 1.7 \\
\hline Hedera & ++ & 119 & 2 & \\
\hline
\end{tabular}

Table 6 List of plant genera that caused at least twice moderate or severe symptoms with the number of total plant exposures (TPE), the endangering potential (EP) from the literature, and the absolute number and relative frequency of moderate and major effects (MME).

\section{Limitations \\ $\nabla$}

Our study had several limitations. The study was only retrospective. Case records of the PIC Erfurt were from self-reported calls, and reflect only information provided by a layperson or health care professional. Exact information about the ingested amount of the plant was often missing. Therefore, it was not possible to investigate the relationship of plant amount and its toxicity. The plant involved in exposure was often not identified by a plant expert and the plant exposure was mostly not confirmed by laboratory analysis.

\section{Conclusions \\ $\nabla$}

In contrast to the development seen by the U.S. PICs, the PIC Erfurt observed a decrease in the frequency of plant exposures in relation to all exposures but not in their absolute numbers in the decade 2001-2010.

While some plants genera like Taxus, Ligustrum, and Ficus were continuously among the most often involved plant genera during the whole study period, exposures to other plant genera like Brugmansia and Datura showed time-dependent changes.

In comparison to all human exposures, the relative frequency of severe symptoms in accidental and intentional plant exposures by abuse is significantly lower, but as high by suicide.

The significantly higher involvement of children resulted mainly in none or mild symptoms. Severe symptoms can mostly be observed in adults with intentional ingestion when poisonous plants are mistaken for eatable.

Because the ingestion of some plants resulted in severe symptoms (Aconitum, Arum, Chelidonium, Datura, Brugmansia, Dieffenbachia, Ricinus, 2 Taxus) and even death (2 Aconitum, 2 Taxus), their dangerousness should not be trivialized.

\section{Conflict of Interest \\ $\nabla$}

All contributing authors state that no conflict of interest is involved with this work.

\section{References}

1 Wolfle J, Kowalewski S. Epidemiology of ingestions in a regional poison control center over twenty years. Vet Hum Toxicol 1995; 37: 367-368

2 Pietsch J, Koch I, Hermanns-Clausen M, Hüller G, Wagner R, Dressler J. Pediatric plant exposures in Germany, 1998-2004. Clin Toxicol 2008; 46: 686-691

3 Jaspersen-Schib R, Theus L, Guirguis-Oeschger M, Gossweiler B, MeierAbt PJ. Serious plant poisonings in Switzerland 1966-1994. Case analysis from the Swiss Toxicology Information Center. Schweiz Med Wochenschr 1996; 126: 1085-1098

4 Kupper J, Reichert C. Intoxications with plants. Ther Umsch 2009; 66: 343-348

5 Fuchs J, Rauber-Lüthy C, Kupferschmidt H, Kupper J, Kullak-Ublick GA, Ceschi A. Acute plant poisoning: analysis of clinical features and circumstances of exposure. Clin Toxicol 2011; 49: 671-680

6 Krenzelok EP, Mrvos R. Friends and foes in the plant world: a profile of plant ingestions and fatalities. Clin Toxicol 2011; 49: 142-149

7 Persson HE, Sjöberg GK, Haines JA, Pronczuk de Garbino J. Poisoning severity score. Grading of acute poisoning. Clin Toxicol 1998; 36: 205213

8 Frohne D, Pfänder HJ. Giftpflanzen, 5th edition. Stuttgart: Wissenschaftliche Verlagsgesellschaft $\mathrm{GmbH} ; 2004$

9 Ritter-Franke S, Bunjes R. Vergiftungsunfälle mit Pflanzen. In: Von Mühlendahl KE, Oberdisse U, Bunjes R, Brockstedt M, editors. Vergiftungen im Kindesalter, 4th edition. Stuttgart, New York: Thieme Verlag; 2003

10 Teuscher E, Lindequist U. Biogene Gifte, 3rd edition. Stuttgart: Wissenschaftliche Verlagsgesellschaft GmbH; 2010

11 Sachs L, Hedderich J. Angewandte Statistik, 12th edition. Berlin, Heidelberg, New York: Springer Verlag; 2006: 256

12 Litovitz T, White NC, Watson WA. Epidemiology of pediatric poison exposures: An analysis of 2003 poison control center data. Clin Ped Emerg Med 2005; 6: 68-75

13 van Eimeren B, Frees B, Gerhard H, Oehmichen E, Schröter C. ARD/ZDFOnlinestudie 1998-2011. Available at http://www.ard-zdf-onlinestudie.de/index.php?id=onlinenutzung00. Accessed November 9, 2011

14 Lin T, Nelson LS, Tsai JL, Hung DZ, Hu SC, Chan HM, Deng JF. Common toxidromes of plant poisonings in Taiwan. Clin Toxicol 2009; 47: 161168

15 Krenzelok EP, Jacobsen TD, Aronis J. Is the yew really poisonous to you? J Toxicol Clin Toxicol 1998; 36: 219-223

16 Kalentzi C, Wattenberg M, Ernstberger J, Deters M, Schaper A, Hentschel $H$. Yew can be really poisonous to you. Clin Toxicol 2010; 48: 309 